UDC 340.13:351.741.073.53(477)

DOI: $10.31733 / 2078-3566-2019-5-30-35$

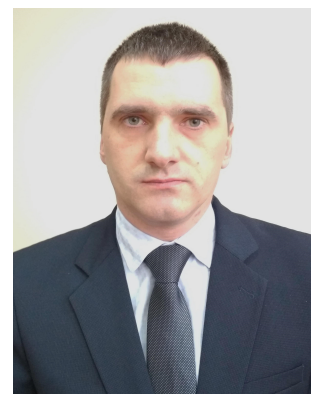

Vitalii BAKAL ${ }^{\circledR}$

Ph.D

(State Research Institute

of the Ministry of Internal Affairs of Ukraine)

\title{
ARRANGING RESOURCES FOR THE NATIONAL POLICE OF UKRAINE: THE LEGAL ASPECT
}

Віталій БакаЛ. ОРГАНІЗАЦІЯ РЕСУРСНОГО ЗАБЕЗПЕЧЕННЯ НАЦІОНАЛЬНОЇ ПОЛІЦІЇ УКРАЇНИ: ПРАВОВИЙ АСПЕКТ. У статті досліджено організаційно-правовий аспект ресурсного забезпечення Національної поліції України. Досліджено нормативно-правові акти що регулюють сферу ресурсного забезпечення поліції та встановлено, що вони достатньо чисельні та різнопланові. На підставі аналізу понять «ресурси», «фінансові ресурси», «матеріально-технічні ресурси» визначено поняття «фінансове забезпечення поліції» та «матеріально-технічне забезпечення поліції».

Фінансове забезпечення поліції - діяльність, що здійснюється в рамках фінансової системи держави у всіх іiї проявах і $є$ формою участі у розподілі коштів шляхом отримання фінансових ресурсів для своєчасного та достатнього забезпечення мобільної готовності поліції до виконання завдань 3 охорони громадського порядку, захисту конституційних прав та свобод громадян України, передбачених ст. 2 Закону України "Про Національну поліцію".

Матеріально-технічне забезпечення поліції слід розуміти як систему товарно-грошових та економічних відносин між органами державної влади, органами МВС, підприємствами, організаціями, особами, 3 одного боку, та підрозділами поліції, 3 іншого боку, у процесі постачання матеріальних, технічних та військових ресурсів для задоволення потреб, необхідних для виконання основних обов'язків та завдань, передбачених ст. 2 Закону України "Про Національну поліцію".

У складі матеріально-технічного забезпечення досліджено окрему категорію - військове постачання. Окреслено організаційну структуру ресурсного забезпечення МВС та Національної поліції, розглянуто функції основних підрозділів ресурсного забезпечення органів системи МВС. Запропоновано основні напрями вдосконалення організації ресурсного забезпечення поліції.

Ключові слова: ресурсне забезпечення, Національна полічія Украӥни, матеріально-технічне забезпечення, фінансове забезпечення

Problem statement. One of the decisive factors in strengthening the law enforcement system, ensuring the readiness of the bodies and subdivisions of the Ministry of Internal Affairs of Ukraine in carrying out the tasks assigned to the Ministry to protect public order and the constitutional rights and freedoms of citizens of Ukraine is the timely and sufficient provision of the National Police with material and technical resources and special equipment. Therefore, clear organizational and legal regulation of the police force is of utmost importance for its resource provision. Effective action and further development in line with the national security objectives of the police depends on it. A significant drawback in the way of implementing the tasks of providing resources to the National Police is the presence in the system of legal regulation of this sphere of an extremely large number of legal acts, as well as legislative and bylaws, so the need for a thorough scientific rethinking of this problem is essential.

Analysis of publications that started solving this problem. The issue of resources for the law enforcement agencies of Ukraine was considered in their works by: O. M. Bandurka, Zh. F. Vikulova, V. V. Vorobiova, S. M. Yermakova, M. S. Ilnytskyi, O. V. Kovaliova, Yu. V. Korechkova, O. O. Krylova, N. Zh. Kuntsa, S. L. Kurylo, P. V. Nielesina, A. Yu. Pantelieieva, N. A. Pelykh, V. M. Plishkina, O. I. Pozharova, A. S. Pronevych, V. M. Raieva, B. B. Ryvkina, R. M. Sapronova, A. Yu. Syniavska, M. D. Smirnova, V. V. Tivanova, I. V. Shamrai, S. O. Shatrava.

(C) Bakal V., 2019

ORCID iD: https://orcid.org/0000-0003-0019-7053

bv_09@ukr.net 
However, these studies mainly concern the resource provision of the internal affairs bodies. The reform of the Ministry of Internal Affairs system has also contributed to the application of new approaches to the provision of resources to both the Ministry of Internal Affairs and the National Police as a whole. There is a need to introduce new approaches to resource support and to organize the work of resource support units.

The article's objective is to study the organizational and legal aspect of the resource provision of the National Police of Ukraine.

Basic content. Regulatory legal acts regulating the sphere of police resources differ in their legal force and sufficiently numerous and diverse.

The main regulatory and legal acts, which directly regulate the resource provision of the Police, are the following: the Constitution of Ukraine, the Civil Code of Ukraine, the Economic Code of Ukraine, the Housing Code of Ukraine, the Law of Ukraine dated July 3, 2015 "On the National Police", the Law of Ukraine dated December 20, 1991 "On Social and Legal Protection of Servicemen and Members of Their Families", Law of Ukraine of February 28, 1991 "On the status and social protection of citizens affected by the Chernobyl disaster", Law of Ukraine of September 18, 1991 "On investment activity", the Law of Ukraine of April 10, 1992 "On leasing of state and municipal property", the Law of Ukraine of October 2, 1992 "On Information", the Law of Ukraine of October 14, 1992 "On labor protection", the Law of Ukraine of October 22, 1993 "On the status of war veterans, guarantees of their social protection", Law of Ukraine "On State Secrets" dated January 21, 1994, Law of Ukraine "On Energy Saving" dated July 1, 1994 (as amended), Law of Ukraine "On Metrology and Metrological Activity" dated February 11, 1998 (as amended), Law of Ukraine from March 3, 1998 "On the transfer of state and communal property", Law of Ukraine from March 24, 1998 "On the status of veterans of military service, veterans of internal affairs bodies and some other persons and their social protection", the Law of Ukraine of March 3, 1999 "On the State Defense Order", the Law of Ukraine of April 20, 2000 "On the planning and development of territories", the Law of Ukraine of January 18, 2001 "On the objects of increased danger", the Law of Ukraine of February 22, 2006 "On the Disciplinary Regulations of the Internal Affairs Bodies of Ukraine", the Law of Ukraine of February 20, 2003 "On Alternative Energy Sources", the Law of Ukraine "On Telecommunications" of November 18, 2003, the Law of Ukraine "On Communications" of January 20, 2005 "On Citizens' Applications", the Law of Ukraine "On Construction Norms" of November 14, 2009, the Law of Ukraine "On Protection of Personal Data" of June 1, 2010 "On Access to Public Information", the Code of Civil Protection of Ukraine of September 10, 2013, the Law of Ukraine of April 10, 2014 "On Public Procurement".

Orders of the Ministry of Internal Affairs of Ukraine: Order of the Ministry of Internal Affairs of Ukraine dated 17.10.2014 No. 1096 "On Approval of the Regulation on the Department of Material Support of the Ministry of Internal Affairs of Ukraine", Order of the Ministry of Internal Affairs of Ukraine dated 25.11.1996 No. 818 "On Approval of the Manual on Automobile Service in the Internal Affairs Bodies of Ukraine" (as amended and supplemented), Order of the Ministry of Internal Affairs No. 535 of 24.05.2002 "On approving the Rules for the Wearing of Uniforms and Signs of Distinction by Persons in Charge of the Interior Ministry Bodies and serviceman by Special Motorized Military Units of the Interior Ministry Troops of the Ministry of Internal Affairs of Ukraine", Order of the Ministry of Internal Affairs of Ukraine No. 1039 dated 10.09.2004 "On the provision of office accommodation and the use thereof by persons in the rank and file of the Ministry of Internal Affairs of Ukraine", registered with the Ministry of Justice of Ukraine on 05.10.2004 under No. 1255/9854 (as amended by Order of the Ministry of Internal Affairs of Ukraine No. 216 dated 12.05.2008, registered with the Ministry of Justice of Ukraine on 31.05.2008 No. 488/15179), Order of the Ministry of Internal Affairs of Ukraine No. 444 of 15.10.2009 "On the approval of documents on the introduction of new means of communication in the telecommunications networks of the Ministry of Internal Affairs of Ukraine", Order of the Ministry of Internal Affairs of Ukraine No. 536 of 07.12.2009 "On the approval of the Program to reduce the consumption of energy carriers by the bodies and subdivisions of the Ministry of Internal Affairs of Ukraine for the years 2010-2014", Order of the Ministry of Internal Affairs of Ukraine No. 259 of 31.05.2011 "On the approval of the Regulation on the Committee on Competitive Bidding of the Ministry of Internal Affairs of Ukraine", Order of the Ministry of Internal Affairs of Ukraine dated 24.12.2012 No. 1190 "On Approval of the Instruction on the Use of Communication Technology in the Internal Affairs Bodies" (registered with the Ministry of Justice of Ukraine on 06.03.2013 under No. 375 / 22907), Order of the Ministry of Health and the Ministry of Internal Affairs of Ukraine dated 31.01.2013 No. 65/80 "On Approval of the Regulations on the medical examination of candidates for drivers 
and drivers of vehicles". (registered with the Ministry of Justice of Ukraine on 22.02.2013 No. 308/22840), Order of the Ministry of Internal Affairs of Ukraine dated 04.12.2013 No. 446 "On Approval of the Instruction on the Procedure for Amendments to the Limits of Energy and Water Consumption for Bodies and Subdivisions of the Ministry of Internal Affairs of Ukraine and the State Migration Service of Ukraine", Order of the Ministry of Internal Affairs of Ukraine dated 07.03.2014 No. 251 "On Approval of the Composition of the Competitive Bidding Committee" (as amended), Order of the Ministry of Internal Affairs of Ukraine dd. 12.05.2014 No. 462 "On Approval of the Comprehensive Plan of Main Activities of Ukraine" (registered with the Ministry of Justice of Ukraine dd. 11.09.2014).

In accordance with Article 105 of the Law of Ukraine No. 580-XIII "On the National Police" dated July 2, 2015, financing and material and technical support of the police is carried out at the expense of the State Budget of Ukraine, as well as other sources not prohibited by law.

In considering the concept of "resource support" it is necessary to define its content, which in accordance with legal norms, including such components as "financial support" and "material and technical support".

The term "resources" (from French "resource" - ancillary means) is interpreted as means, stocks, opportunities, sources of income. Means are the techniques, means of action to achieve something, and the objects, facilities (or their totality) needed to carry out an activity.

Analyzing the "financial support" and "material and technical support" of the law enforcement agencies, V. M. Teslenko [7, p.10] defined the "resource support of the Ministry of Internal Affairs" as "the process of circulation of material goods (means of production and consumption items) organized by the state and its agencies and the most rational delivery of them from producers to consumers of the Ministry of Internal Affairs". In general, agreeing with the point of view of V.M. Teslenko, more successful, in our opinion, is the definition of A. N. Bandurka, who by material, technical and financial support offered to understand the system of commodity-money and economic relations that arise between the services of the Ministry of Internal Affairs, authorities, enterprises, organizations, individuals, on the one hand, and the bodies of the Ministry of Internal Affairs, on the other hand, in the process of centralized supply of material, technical and military resources (raw materials, fuel, equipment, tangible property, weapons, ammunition); performing purchase and sale agreements (wholesale trade), fund sales, commission and retail sale of products and means of production; providing material and technical assistance and financing their activities. [8, c.17].

As it is known, material and technical maintenance is a difficult social and economic process: at the market forms of management of the enterprise-manufacturers becomes free in realization of economic activity, functioning on principles of self-supporting, self-financing, free business and competition. This process consists of several stages: preparation, conclusion of contracts, receipt of resources, their transfer to consumers.

With these matters cleared away, many scientists and practitioners consider the material and technical support as a resource.

The content of the concept of "resource provision" of the National Police "derives from its purpose: the provision of the police with appropriate financial sources, stocks of material and technical means necessary to perform the main duties and tasks provided for in Article 2 of the Law of Ukraine "On the National Police".

Depending on the role, material presentation and specificities of the impact on the functioning of the National Police, these resources can be classified by type and divided into financial, material and technical resources.

Financial resources are the totality of all trust funds of the police funds necessary for its functioning; revenues streams and payments carried out. Financial resources, in turn, are divided into centralized and decentralized ones.

Material resources - buildings (roofs, facades, service and auxiliary premises, dormitories and service apartments) territory (roads, parking lots, park zone, fencing, polygons) servicing economic structure (workshop, household equipment, transport, telephone stations, heat supply units, heating, electric and municipal networks, water supply, boilers, substations and distribution electric devices); social structures (canteens, cafeterias, assembly halls, departmental health care institutions and sanatoriums, children's health camps, recreation centers, libraries, museums, cultural centers); sports facilities (clubs, stadiums, bases), furniture, equipment, building materials, stationery, fuel, spare parts; uniforms.

Technical resources include security (control and alarm systems, technical devices); computers and other office equipment, special equipment, means of communication and the like. 
Taking the above-mentioned, we shall determine that the financial provision of the police is an activity that is carried out within the framework of the financial system of the state in all its manifestations and is a form of participation in the distribution of funds by obtaining financial resources for timely and sufficient to ensure the mobile readiness of the police to perform tasks to protect public order, the protection of constitutional rights and freedoms of citizens of Ukraine, as provided for in Article 2 of the Law of Ukraine "On the National Police".

The material and technical support of the police should be understood as a system of commodity-money and economic relations between public authorities, bodies of the Ministry of Internal Affairs, enterprises, organizations, individuals, on the one hand, and police units, on the other hand, in the process of supply of material, technical and military resources to meet the needs necessary for the performance of basic duties and tasks provided for in Article 2 of the Law of Ukraine "On the National Police".

A separate category of material and technical support should also be distinguished military supply, the main purpose of which is to ensure that the police are provided with special-purpose equipment in accordance with established standards, time sheets and states, namely: weapons, ammunition, ammunition, ammunition, equipment, military and special equipment, food and reserve stocks.

The process of providing logistical support to the police is divided into several interrelated stages: studying the needs for a certain type of material assets and appropriate financial capabilities; conducting tenders for the supply of products and / or services; preparing and concluding contracts; obtaining resources, transferring them to consumers (the police).

Financial, material and technical support and military supplies within the Ministry of Internal Affairs (of which the National Police is a part) are dealt with the limits of their competence:

The Internal Audit Department of the Ministry of Internal Affairs, the functions of which include: 1) assessment of: efficiency of the functioning of the internal control system of the Ministry of Internal Affairs; the degree of implementation and achievement of the objectives defined in the strategic and annual plans; efficiency of planning and implementation of budget programs and the results of their implementation; management of budget funds; quality of administrative services and performance of control and supervision functions, tasks defined by legislative acts; preservation of assets and information; use and safety of assets; correctness of accounting and reliability of financial and budgetary reporting; risks that negatively affect the performance of functions and tasks of the Ministry and other internal audit objects; reliability, efficiency and effectiveness of information systems and technologies; 2) monitoring and analysis of individual business operations in order to identify and assess risks, including in the organization of public procurement; compliance with financial and economic and budgetary discipline.

Department of State Property and Resources of the MIA, which: 1) carries out: management of state property objects within the powers of the Ministry of Internal Affairs, defined by law; state supervision over labor protection; 2) Organizes: the development, coordination and functioning of the Ministry of Internal Affairs' communications and telecommunications system; the management and monitoring of the unified digital departmental telecommunications network of the Ministry of Internal Affairs and the fixed radio frequency resource of Ukraine; in accordance with the established procedure, the material, technical and resource support for the activities of the Ministry of Internal Affairs apparatus and of territorial bodies, institutions and enterprises under the management of the Ministry of Internal Affairs and the National Guard; 3) Controls and takes measures to ensure fire safety.

The Department of Financial and Accounting Policy of the Ministry of Internal Affairs prepares budget figures; organizes: financial support for the activities of the Ministry's staff and of budget-funded institutions and organizations in the area of administration of the Ministry of Internal Affairs and central executive authorities, the activities of which are channelled and coordinated by the Cabinet of Ministers through the Minister of Internal Affairs; remuneration, social and other payments; and measures to maintain accounting records of financial and economic activities and to prepare reports in the institutions of the Ministry of Internal Affairs.

The main units of the National Police, which provide resources, are the following:

The Department of Financial Support and Accounting has relevant functions similar to those of the Department of Financial and Accounting Policy of the Ministry of Internal Affairs. Relevant departments (divisions) of financial support and accounting are introduced in the territorial subdivisions of the police;

The Internal Audit Department, which in accordance with the Procedure of internal audit and formation of internal audit units, approved by the Cabinet of Ministers of Ukraine on 
September 28, 2011 № 1001, is organizationally and functionally independent, is directly subordinate and accountable to the Chairman of the National Police of Ukraine. The relevant internal audit department also has territorial subdivisions of the police;

The Property Management Department, which plans and organizes the procurement and further management of material resources necessary for the performance of the tasks assigned to the police authorities, submits proposals on the efficient use of public property in the field of police management, and participates in the implementation of the state policy in the field of property relations regulation and organizes the attraction of investments and capital construction management; organizes and provides material, technical and resource support to the police, including vehicles, weapons, special equipment, fuel and lubricants, uniforms, police officers, and other types of property required to perform their tasks.

The entire structure of police management has appropriate financial and accounting departments (divisions), internal audit departments ("sectors"), logistics and material and technical management departments ("divisions"), stresses the importance of resources for the National Police of Ukraine. As A. I. Subbot notes, the process of logistical support of the internal affairs bodies is mainly related to specific political and historical processes and directly affects the stability and effectiveness of law enforcement agencies. This is a rather complicated socioeconomic process. In the conditions of the market form of management, the studying of the market, searching of the most profitable suppliers, defining of requirements in resources, and also the control over performance of delivery conditions acquires importance [10, p. 17]. In support of the above mentioned A. H. Honchar notes that almost $30 \%$ of all supply volumes are carried out centrally and planned through the state order by means of distribution. All additional deliveries are organized directly through the conclusion of contracts between the subjects of delivery and the bodies of the National Police of Ukraine. Despite the exceptional need to improve the efficiency of the National Police of Ukraine, the state of its material and technical support is not sufficient, which results in a threat to the national security of the state. [Honchar]

Conclusion. Summarizing it should be pointed out that the reasons for the decrease in the level of resources of the National Police of Ukraine are the chaotic development of the economic and political situation in the country. When organizing the resource provision of the police, it is necessary to take into account the current state of the Ukrainian economy first of all. There is a need to study and widely introduce the leading experience of other countries' police agencies into the organization of resource provision to the police.

\section{1. Про Національну поліцію : Закекесеs України від 02.07.2015. URL :} http://www.zakon.rada.gov.ua/go/580-19.

2. Словник української мови: академічний тлумачний словник : в 11-и т. $(1970-1980)$. URL: http://sum.in.ua.

3. Тесленко В.М. Правовое регулирование материально-технического и военного снабжения в системе МВД Российской Федерации : автореф. дисс. .. канд. юрид. наук. Киев, 1992. ків, 2004.

4. Бандурка O.M. Теорія і практика управління органами внутрішніх справ України. Хар-

5. Ільницький М.С. Організація фінансового та матеріально-технічного забезпечення органів внутрішніх справ України. Форум права. 2009. № 1. С. 222-230. URL: http://www.nbuv.gov.ua/ejournals/FP/2009-1/09imcvcu.pdf.

6. Порядок здійснення внутрішнього аудиту та утворення підрозділів внутрішнього аудиту: затв. постановою Кабінету Міністрів України від 28 вересня 2011 p. N 1001. URL : https://zakon.rada.gov.ua/laws/show/1001-2011-\%D0\%BF.

7. Суббот А. І. Фінансове та матеріально-технічне забезпечення правоохоронних органів як складові їх безпечної діяльності. Віче. 2012. № 24. С. 16-18. URL : http://nbuv.gov.ua/UJRN/viche_2012_24_8.

8. Гончар А. Г. Принципи та стадії фінансування і матеріально-технічного забезпечення Національної поліції України. Науковий вісник Національної академії внутрішніх справ. 2018. № 1. C. 265-276.

9. Рішення Рахункової палати України від 11 квітня 2018 року № 10-2 «Про результати аудиту ефективності використання бюджетних коштів, виділених на забезпечення діяльності підрозділів, установ та закладів Національної поліції України». URL: R_RP_10-2_2018.pdf.

Received to editoriall office 06.12.2019

1. Pro Natsionalnu politsiyu: Zakon Ukrainy vid 2 lyp. 2015 r. No. 580-VIII [Law of Ukraine "On National Police" from July 2, 2015, No. 580-VIII]. (n.d.). zakon.rada.gov.ua. URL : http://www.zakon.rada.gov.ua/go/580-19 [in Ukr.] 
2. Slovnyk ukrainskoi movy: akademichnyi tlumachnyi slovnyk $(1970-1980)$. [Dictionary of the Ukrainian Language: Academic Interpretative Dictionary $(1970$ - 1980): In 11 volumes]. URL: http://sum.in.ua. [in Ukr.]

3. Teslenko V. M. (1992) Pravovoye regulirovaniye materialno-tekhnicheskogo i voyennogo snabzheniya v sisteme MVD Rossiyskoy Federatsii. [Legal regulation of material and technical and military supplies in the system of the Ministry of Internal Affairs of the Russian Federation: author. dis. for the competition degree of $\mathrm{Ph}$. D. in Law. Kyiv. [in Russ.]

4. Bandurka O. M. (2004) Teoriia i praktyka upravlinnia orhanamy vnutrishnikh sprav Ukrainy. [Theory and practice of management of law-enforcement bodies of Ukraine: monograph]. Kh. [in Ukr.]

5. Ilnytskyi M. S. (2009) Orhanizatsiia finansovoho ta materialno-tekhnichnoho zabezpechennia orhaniv vnutrishnikh sprav Ukrainy. [Organization of financial and logistical support of the bodies of internal affairs of Ukraine]. Forum prava. No. 1. P. 222-230. URL: http://www.nbuv.gov.ua/ejournals/FP/2009-1/09imcvcu.pdf. [in Ukr.]

6. Poriadok zdiysnennia vnutrishnoho audytu ta utvorennia pidrozdiliv vnutrishnoho audytu, zatverdzhenoho postanovoiu Kabinetu Ministriv Ukrainy vid 28 veresnia 2011 roku № 1001. [ Procedure for internal audit and establishment of internal audit units, approved by the Cabinet of Ministers of Ukraine Decree No. 1001 of September 28, 2011. URL : https://zakon.rada.gov.ua/laws/show/1001-2011$\% \mathrm{D} 0 \% \mathrm{BF}$. [in Ukr.]

7. Subbot A. I. (2012). Finansove ta materialno-tekhnichne zabezpechennia pravookhoronnykh orhaniv yak skladovi ikh bezpechnoi diialnosti [Financial and logistical support of law enforcement bodies as part of their safe activities]. Viche, 24, 16-18. URL : http://nbuv.gov.ua/UJRN/viche_2012_24_8. [in Ukr.]

8. Honchar A. H. (2018) Pryntsypy ta stadii finansuvannia i materialno-tekhnichnoho zabezpechennia Natsionalnoi politsii Ukrainy. 2018. № 1 (106).[Principles and stages of financing and logistics of the National Police of Ukraine. No. 1 (106)]. Scientific Bulletin of the National Academy of Internal Affairs. P. 265-276. [in Ukr.]

9. Rishennia Rakhunkovoi palaty vid 11 kvitnia 2018 roku № 10-2 «Pro rezultaty audytu efektyvnosti vykorystannia byudzhetnykh koshtiv, vydilenykh na zabezpechennia diialnosti pidrozdiliv, ustanov ta zakladiv Natsionalnoi politsii Ukrainy». [The decision of the Accounting Chamber of April 11, 2018 № 10-2 "On the results of the audit of the effectiveness of the use of budgetary funds allocated to support the activities of units, institutions and institutions of the National Police of Ukraine"]. URL: R_RP_10-2_2018.pdf. [in Ukr.]

Received to editoriall office 06.12.2019

\section{Summary}

The article deals with organizational and legal aspect of the resource provision of the National Police of Ukraine. Regulatory and legal acts regulating the sphere of resource provision of the police are studied and established that they are rather numerous and diverse. Based on the analysis of the concepts of "resources", "financial resources", "material and technical resources", the concept of "financial provision of the police" and "material and technical provision of the police" was defined. As part of the material and technical support, a separate category - military procurement - was studied. The organizational structure of the resource support of the Ministry of Internal Affairs and the National Police is determined, and the functions of the main resource support units of the bodies of the Ministry of Internal Affairs are considered. The main directions for improving the organization of resource provision to the police are proposed.

Keywords: resources, National Police of Ukraine, material and technical support, financial support. 